\title{
Overcoming Elderly Anxiety through Kidung Wargasari
}

\author{
Putu Mastiningsih \\ Department of Tocology, Sekolah Tinggi Kesehatan Bina Usada Bali, Indonesia
}

Received March 14, 2020; Revised April 10, 2020; Accepted April 27, 2020

Copyright $\mathrm{C} 2020$ by authors, all rights reserved. Authors agree that this article remains permanently open access under the terms of the Creative Commons Attribution License 4.0 International License

\begin{abstract}
Anxiety disorders can be interpreted as a heightened tension that results in feelings of helplessness, loss of control and excessive subjective judgment of the interpersonal communication process. Anxiety disorders an ongoing basis often haunt the health of those who have reached a late age (the elderly). However, the elderly in the Tresna Werdha Foundation area, Blahkiuh village, Abiansemal, Badung Regency, Bali Province did not. They are known to love singing the Wargasari. They do not appear to have anxiety disorders about health as the elderly in general. The purpose of this study was to analyze the effectiveness of Wargasari as therapy in dealing with anxiety disorders among the elderly in the Tresna Werdha Foundation area, Blahkiuh village, Abiansemal, Badung Regency, Bali Province. This type of research is quantitative with a pretest-posttest one-group pre-experimental design. A sample of 67 elderly, who experienced anxiety and selected in total sampling, data were analyzed with the Wilcoxon Signed Rank Test. The results showed that the average anxiety before giving Wargasari therapy was 36.90 (severe anxiety), and after being given Wargasari therapy the average was 23.00 (moderate anxiety). The p-value of $0.001<\alpha(0.05)$ means, there is a significant influence between Wargasari on anxiety. The results of this study are used as adjunctive therapy in the management of anxiety in the elderly. Based on these results, it can be concluded that the Wargasari has a significant effect on the anxiety level of the Elders in the Tresna Werdha Foundation area, Blahkiuh village, Abiansemal, Badung Regency, Bali Province. This research output is dedicated to enrichment in public health studies and cultural studies. The results of this study are expected to be useful for researchers interested in researching anxiety disorders, Balinese cultural traditions and health behaviors of the elderly.
\end{abstract}

Keywords Anxiety, Elderly, Kidung Wargasari

\section{Introduction}

Health and the development of science and technology are interrelated. During this time the development of science and technology has made a positive contribution to health, especially welfare which can be seen from life expectancy (UHH) [4]. Life expectancy and the number of elderly increase and reflect health improvements. But on the other hand, it is a dilemma because it raises various health and economic problems in the future. At present, the world demographic is changing, along with the increase in health development, indirectly causing (UHH) to increase and causing the proportion of the population aged $\geq 60$ years to also increase.

In Indonesia, emotional disturbances that occurred at the age of 55-64 years were $8 \%$, aged $65-74$ years were $10 \%$ and at the age of more than 75 years were $13 \%$ of the total population of Indonesia. Some districts in Bali, Badung is one of the regencies has a population with an old age structure. This can be seen from the proportion of elderly people aged $\geq 65$ years in Badung exceeding seven percent which is $10.49 \%$ of the total population of Badung. One of the districts with the highest number of elderly people in the Badung Regency is Abiansemal District. Which has 11,900 inhabitants consisting of 6,500 women and 5,400 men. Among the four puskesmas in Abiansemal Sub-district, the highest number of elderly is in the Abiansemal Puskesmas area, namely the Tresna Werdha Foundation area with 67 people consisting of 12 women and 55 men. Teresna Werdha Foundation is a combination of elderly groups in Blakiuh Village. Which is held every Friday at the Puskesmas Abiansemal I, they have routine activities carried out every week namely the elderly gymnastics. Besides that, many elderly people experience complaints such as back pain and tingling, anxiety about their condition begins to emerge, therefore every month a health check is carried out such as checking blood pressure, cholesterol, gout, and blood sugar which aims to find out health in him so anxiety experienced can be reduced.

Aging is a natural process that can not be avoided and running continuously. The aging process involves a 
variety of changes that will have an impact on decreasing physical, mental, psycho-social conditions, changes related to work and the social role of the elderly. Change can result in the function of social roles in certain sectors [22]. Changes in physical and mental performance that continue to decline often result in a psycho-social crisis for social roles. The existence of a social role indicates the existence of social position [12]. Psycho-social crises can also be caused due to loss of position, access, and power over their social roles.

The significant physiological and psychological decline in elderly body function is often accompanied by increased health problems and the problems with access to social roles. In that situation, the elderly need integrated treatment for their emotional stability. The mental health problems often occur in the elderly are excessive anxiety, extreme depression, insomnia, paranoia, and dementia. If the elderly experience these problems until then the condition is a disturbance in the elderly's activities every day.

Anxiety is an obscure and pervasive concern related to feelings of uncertainty and helplessness. This emotional state has no specific object. Anxiety is experienced subjectively and communicated interpersonal [11]. Interpersonal, objective specifications require management [18]. Management can be done in two ways, namely pharmacology and non-pharmacology. Pharmacological management can indeed help but only temporarily and is dependent [9]. Non-pharmacological management can also be used as an alternative to deal with anxiety problems of non-pharmacological use such as music therapy, relaxation of breath in the Mekidung for the elderly group there. But some of them know the type of chanting and some of them also exist as chanting leaders in Banjar. The group leader said, there had never been any research on "Overcoming Elderly Anxiety through Wargasari Song in Blahkiuh Village, Abiansemal Badung Regency". Based on the description above, the researchers wanted to examine by Overcoming the Elderly Anxiety Through Wargasari Therapy in Blahkiuh Village, Abiansemal Badung Regency, Bali.

In the village of Blahkiuh, Badung Regency, Bali sacred songs in the form of songs have often been heard by the community. The song is usually sung at traditional ceremonies because it contains praise and adoration to God Almighty. The implementation of traditional ceremonies in Bali is carried out accompanied by material sacred offerings $[13,21,27,28,30]$. The contents of a hymn contain material on Balinese Hinduism which is lived in such a way as a sacred song with a beautiful and charming rhythm [29]. Something beautiful and charming can affect a positive response $[19,20,23,24,32]$. Sanctity in the sacredness of ceremonies and shrines requires educative Hinduism [15]. A type of ballad that educates and is familiar in Balinese society includes the Wargasari. Kidung Wargasari is a yadnya to the deity, the Balinese convey when performing traditional ceremonies.

The Balinese people in general only know two kawitan stanzas from the kidung wargasari text. When listening or singing a hymn full of appreciation, the meaning of the hymn can make peace for them. Slow rhythmic songs when heard will bring a feeling of calm. A peaceful and family atmosphere is needed in a zonation that is conducive to building vibrations for the implementation of traditional ceremonies. As zoning implies a certain process of acceptance, the atmosphere and dynamics of participation [14].

The hubbub of the atmosphere requires discourse or dominant and agent participation [16,17]. The peace and excitement of the atmosphere is built up through the Wargasari song can lead to the forms of calm and comfort needed during carrying out the Yadnya deity ceremony. The positive influence of culture can lead certain people to satisfaction achievement $[25,31]$. Just as an art form is favored because it is rhythmic and meaningful, the hymns of Wargasari as sacred songs can significantly influence the peace or tranquility of those who understand them.

\section{Materials and Methods}

This research is a pre-experimental study with a one-group pretest-posttest design in which the characteristic of this type of research is to reveal the causal relationship by involving a group of subjects. The subject group was observed again after the intervention [9]. The population in this study is the elderly who experience anxiety in the Tresna Werdha environment as many as 30 people. The sampling technique in this study uses total sampling. Researchers used 30 samples, namely 30 all populations were sampled. Based on a preliminary study on Friday 11 January 2019, direct interviews were conducted with 10 elderly people. Of the 10 people interviewed 8 people, who experienced anxiety with complaints such as feeling tired quickly, muscles feeling tense and easy to forget. The measuring instrument used is HRS-A (Hamilton Rating Scale for Anxiety).

\subsection{Characteristics of Respondents (Results)}

Table 1. Characteristics of Respondents by Age at the Tresna Werdha Foundation area in Blahkiuh Village, Abiansemal, Badung, Bali

\begin{tabular}{|c|c|c|}
\hline Age & Frequency & Percentage \\
\hline & (f) & $(\%)$ \\
\hline $60-70$ & 15 & 50 \\
\hline $71-80$ & 13 & 43,3 \\
\hline $81-90$ & 2 & 6,7 \\
\hline$>90$ & 0 & 0 \\
\hline Total & 30 & 100 \\
\hline
\end{tabular}

Based on the above table, it can be seen that respondents 
numbered 30 people with ages $60-70$ years, 15 people $(50.0 \%)$, aged $71-80$ years as many as 13 people $(43.3 \%)$ and aged $81-90$ ie 2 people $(67 \%)$.

\subsection{Univariate Data Analysis}

Average Anxiety in the Elderly before and After Given the Kidung Wargasari (Results)

Table 2. Average Anxiety in the Elderly Before and After Given the Kidung Wargasari at the Tresna Werdha Foundation area in Blahkiuh Village, Abiansemal, Badung

\begin{tabular}{|c|c|c|}
\hline Classification & Average & Standard Deviation \\
\hline Dismay & & \\
\hline Before Anxiety & 36,90 & 6,860 \\
\hline After anxiety & 23,00 & 3,029 \\
\hline
\end{tabular}

In the table above, it can be seen that the respondent has an average level of anxiety before being given Wargasari therapy which is 36.90 with a standard deviation of 6,860 while the average level of anxiety after the Kidung Wargasari singing is 23.00 with a standard deviation of 3.029 .

\subsection{Bivariate Data Analysis}

The Influence of Kidung Wargasari on Anxiety in the Elderly at Tresna Werrdha Foundation area in Blakiuh Village, Abiansemal, Badung (Results)

Table 3. Influence of Kidung Wargasari on Anxiety in the Elderly in Tresna Werdha Foundation area in Blakiuh Village, Abiansemal, Badung

\begin{tabular}{|l|l|l|l|l|l|}
\hline \multicolumn{5}{|c|}{ Elderly Anxiety Classification at Tresna Werdha Foundation area } \\
\hline & N & Average & $\begin{array}{l}\text { Average } \\
\text { difference }\end{array}$ & SD & P \\
\hline Pre-Test & 30 & 36,90 & 13,90 & 6,680 & 0,001 \\
\hline Post-Test & 30 & 23,00 & & 3,029 & \\
\hline
\end{tabular}

In the table above, it can be seen the average before being given the Wargasari Therapy $=36.90$ with $\mathrm{SD}=$ 6,860 while the average after being given Wargasari Therapy $=23,00$ with $\mathrm{SD}=3,092$. The mean difference was 13.90 with $p$-value $=0.001$, which means the value of $\mathrm{p}<0.05$, meaning Ho was rejected and Ha was accepted. So, it can be concluded that there is a significant influence of the Kidung Wargasari on anxiety in the elderly in Tresna Werdha Foundation area.

\subsection{Average Anxiety before Being Given Wargasari Therapy in Tresna Werdha Foundation area, Blakiuh Village, Abiansemal, Badung (Discussion)}

This study used 30 respondents, with the age range of respondents in the range of 60-70 years as many as 15 people $(50.0 \%), 71-80$ years as 13 people $(43.3 \%), 81-90$ years as 2 people $(6.7 \%)$. In table 1 , it can be seen that 30 respondents had an average level of anxiety before being given it. Citizens which is 36.90 with a standard deviation of 6.860. As we get older, there will be a decrease in bodily functions in the elderly, both physical and physiological.

Anxiety disorder can be interpreted as tension. That peaks resulting in anxiety and loss of control due to the subjective assessment of the interpersonal communication process. This can also be interpreted as an uncertain feeling of helplessness [8]. Handling in non-pharmacological means that, the tune of Wargasari residents can also reduce the anxiety experienced by someone because Wargasari in Mekidung can make a person calmer.

\subsection{Average Anxiety after Being Given Wargasari Therapy against Anxiety in the Elderly at Tresna Werdha Foundation area in Blahkiuh Village, Abiansemal, Badung (Discussion)}

The average level of anxiety has been given the Wargasari Therapy that is 23.00 with a standard deviation of 3.029. This shows the decline in the average value of anxiety after given Wargasari. Hymns in the form of songs have often been heard by the public. When listening or singing a hymn full of appreciation, the meaning of the hymn can make calm in every listener. A slow rhythmic tune when heard will bring a feeling towards calmness. The song is included in this type of spiritual music into the auditory system is then accepted by the limbic system, especially the amygdala and hippocampus. The limbic system has a connection with the hypothalamus. The hypothalamus will send signals to the pituitary gland, which controls the body's hormones. This signal is received by the pituitary gland as a command to decrease cortisol, known as a stress hormone. The body responds to stress by releasing the hormones epinephrine and norepinephrine. When singing a Wargasari, the residents will experience a state of relaxation and peace. This situation will inhibit the release of the hormones cortisol, epinephrine, and norepinephrine.

\subsection{Analysis of the Influence of the Wargasari Therapy on Anxiety in the Elderly at the Tresna Werdha Foundation area in Blahkiuh Village, Abiansemal, Badung (Discussion)}

In table 2 the Wilcoxon Signed Rank Test statistic results obtained a p-value of 0.001 at $\alpha(0.05)$ p-value $<\alpha$ which means there is a significant influence between the Wargasari and Citizens against Anxiety in the Elderly $\mathrm{p}$ $(0.001)<\alpha(0.05)$. This is because when performing the cider's chanting, there will be a transfer of brain waves that are from alpha waves to theta waves. This will make the body release the hormone endorphin which makes a person feel happy. This hormone will restore the effects of the cortisol hormone so that feelings of anxiety become 
reduced or disappear.

This study is in line with research conducted about the differences in the influence of classical music therapy and traditional Javanese music on anxiety levels found a difference between the effects of classical music therapy and traditional Javanese music on anxiety levels in the elderly. Where traditional Javanese music therapy is more influential in decreasing the level of anxiety of the elderly [26].

\section{Conclusions}

The average anxiety before the Wargasari Therapy was given was at the level of severe anxiety $(36,90)$. The average anxiety of the elderly after being given Wargasari Therapy is at a moderate level of anxiety (23.00). There is a significant influence of Wargasari Therapy on anxiety in the elderly in the Tresna Werdha Foundation area in Blahkiuh Village, Abiansemal, Badung with a $\mathrm{p}$-value of 0.001 meaning $\mathrm{p}<0.05$.

\section{Acknowledgements}

Special Thanks to the all participants who have participated in the success of our research design until it can be realized in the form of scientific article.

\section{REFERENCES}

[1] Lilik M. Azizah. Keperawatan Lanjut Usia, Graha Ilmu, Yogyakarta, 2011.

[2] R. Anggraeni, Manfaat Menyanyi Untuk Kesehatan Tubuh, Online Available From https://lifestyle.sindonews.com/rea d/944030/155/manfaat-menyanyi-untuk-kesehatan-tubuh-1 419934249 .

[3] Babad Bali. Aneka Geguritan. Online Available from http://babadbali.com.

[4] Chayatin N., Mubarak W. Ilmu Keperawatan Komunitas: Pengantar dan Teori. Jakarta, Salemba Medik, 2009.

[5] Depkes RI. Riset Kesehatan Dasar. Online Available From http://www.depkes.go.id.

[6] Hawari D. Manajemen Stress, Cemas dan Depresi. Jakarta, FK UI, 2013.

[7] Junaidi Z. Pengaruh Terapi Musik Langgam Jawa Terhadap Penurunan Tingkat Kecemasan Pada Lansia di Purworejo. Online Available From http://ejournal.stikesmukla.ac.id.

[8] Nasir A. Dasar-Dasar Keperawatan Jiwa: Pengantar dan Teori. Jakarta, Salemba Medika, 2011.

[9] Nursalam. Metodologi Penelitian Ilmu Keperawatan Edisi 4. Jakarta, Salemba Medika, 2016.
[10] Pratiwi, R. Pengertian Kecemasan. Online Available From http://psikologi.or.id.

[11] Stuart G. Buku Saku Keperawatan Jiwa Edisi 5. Jakarta, EGC, 2012.

[12] G. Marhaendra Wija Atmaja, Ida Ayu K. Arniati, G. Yoga Kharisma Pradana. Implications of The Enacment of Law Number 6 of 2014 on The Position of Villages in Bali, Indonesia, Asia Life Sciences, 2019, Vol. 28, No.2, 295-310.

[13] N. Wayan Karmini, N. Made Ruastiti, G. Yoga Kharisma Pradana. Tumpek Uduh Ceremony as an Education Medium in The Preservation on Natural Environtment in Bali: A Case Study in Canggu Village, Kuta Utara District, Badung Regency, Bali-Indonesia, Asia Life Sciences, 2019, Vol. 28, No. 1, 115-139.

[14] N. Wayan Karmini, N. Made Ruastiti, G. Yoga Kharisma Pradana. Discursusing of The Zonation System in Accepting New Student in 2018: Case Study in Denpasar City, The Proceeding of Posibilities and Probabilities in Higher Education of Asia, 152-160, 2019.

[15] N. Wayan Karmini, N. Putu Dyatmikawati, G. Ayu Suasthi, N. Ketut Sri Kusuma Wardhani, G. Yoga Kharisma Pradana. Objek Wisata Pura Tirta Empul Sebagai Media Pendidikan Multikultural Bagi Generasi Milenial Pada Era 4.0, Ganaya: Jurnal Ilmu Sosial Humaniora, 2020, Vol 2, No. 2-3, 21-29.

[16] G. Yoga Kharisma Pradana. Diskursus Fenomena Hamil di Luar Nikah Dalam Pertunjukan Wayang Joblar, Online Journal of Cultural Studies, 2012, Vol. 1, No. 2, 11-27.

[17] G. Yoga Kharisma Pradana. Deconstruction Powers of Relations Behind the Shadow Puppet Performance for Tourism in Ubud Village, Bali. The Proceeding of Building Collaboration and Networking in Globalized World, 115-124, 2017

[18] G. Yoga Kharisma Pradana. Filsafat Ilmu Pariwisata. Denpasar, STPBI, 2017

[19] G. Yoga Kharisma Pradana. Implications of Commodified Parwa Shadow Puppet Performance for Tourism in Ubud, Bali, Journal of Business on Hospitality and Tourism, 2018, Vol.4, No. 1, 70-79. DOI: http://dx.doi.org/10.22334/jbhos t.v4i1.103.g111.

[20] G. Yoga Kharisma Pradana. Innovation in Cenk Blonk Performance: A Strategy of Empowering Local Language Through Balinese Shadow Puppet, The Proceeding of the International Conference on Local Language, 173-182, 2018.

[21] G. Yoga Kharisma Pradana. The Meaning of Makotek Tradition at The Munggu Village on The Global Era, The Proceeding of the International Bali Hinduism, Tradition and Intereligious Studies, 122-128, 2018.

[22] G. Yoga Kharisma Pradana. Sosiologi Pariwisata. Denpasar, STPBI Press, 2019.

[23] I Wayan Rai S., Made G. Indra Sadguna, I G. Agus Jaya Sadguna, G. Yoga Kharisma Pradana. Tifa from The Land of Papua: Text and Context, Asia Life Sciences, 2019, Vol. 28, No. 2, 335-354.

[24] N. Made Ruastiti, G. Yoga Kharisma Pradana, I Gusti K. 
Purnaya, K. Shanty Muni Parwati. The Royal Dinner Party Puri Anyar Kerambitan Tabanan: A Sustainable Cultural Tourism Attraction Based on Local Community. The Proceeding of the International Conference on Social Science, 1448-1459, 2018. https://doi.org/10.2991/icss-18.2018.305.

[25] I P. Windhu Tejayadhi, I N. Laba, G. Yoga Kharisma Pradana. The Effect of Organizational Culture on Employee Satisfaction in Mercure Resort Sanur Bali Hotel. The International Journal of Green Tourism Research and Applications, 2019, Vol. 1, No. 1, pp. 63-72.

[26] I G. Yudiana Putra. Perbedaan Pengaruh Musik Klasik dan Musik Tradisional Jawa Terhadap Tingkat Kecemasan Ditinjau Dari Latarbelakang Pendidikan Lansia di Panti Werdha Hanna Yogyakarta. Surakarta, UNS, 2014.

[27] G. Yoga Kharisma Pradana, Komang Trisna Pratiwi Arcana. Balinese Traditional Homestay in a Sustainable Tourism Entering Millennial Era. Journal of Xi'an University of Architecture \& Technology, 2020, Vol. 12, No.3, pp. 4208-4217.

[28] N. Made Ruastiti, G, Yoga Kharisma Pradana. The Ideology Behind Sesandaran Dance Show in Bali. Journal of Sociology and Social Anthropology, 2020, Vol. 11, No. 2, pp.78-85.

[29] Ida Ayu K. Arniati, G. Marhaendra Wija Atmaja, G. Yoga Kharisma Pradana. Moral and Religious Values in The Geguritan Dharma Prawerti Song in Bali. International Journal of Innovation, Creativity and Change, 2020, Vol.12, No.1, pp. 432-446.

[30] G. Yoga Kharisma Pradana, I N. Suarka, Anak Agung B. Wirawan, I N. Dhana. Religious Ideology of The Tradition of The Makotek in The Era of Globalization. Electronic Journal of Cultural Studies, 2016, Vol.9, No. 1, pp. 6-10.

[31] G. Yoga Kharisma, K. Shanty Muni Parwati. Local-Wisdom-Based Spa Tourism in Ubud Village of Bali, Indonesia. Russian Journal of Agricultural and Socio-Economic Sciences, 2017, Vol. 8, No. 68, pp. 188-196.

[32] G. Yoga Kharisma Pradana, I W. Pantiyasa. Makotek as Tourist Attraction in Munggu Village. The Proceeding of $2^{\text {nd }}$ The International Conference on Tourism, Gastronomy and Tourist Destination (ICTGTD 2018). Jakarta : Atlantis Press. 